\section{Royal Aeronautical Society Anniversary Exhibition}

A sPECrac exhibit, which has been formed by the Royal Aeronautical Society to mark the seventieth anniversary of its foundation, was inaugurated in the Science Museum, South Kensington, on the occasion of the Society's annual reception on May 21, and will be available to the public until June 22. The exhibit comprises aeronautical objets d'art, aeronautical trophies, medals, engravings, stamps and rare or unique articles connected with ballooning and aviation, many of which have been lent by private collectors. The Society will show the first Council Minutes (January 12, 1866) and MSS. relating to outstanding events in its history; the first pilot's certificate issued in Great Britain and granted to Lieut.-Col. J. T. C. Moore-Brabazon-now president of the Society--will be included.

\section{Scientific Instruments in Relation to Textiles}

DuRING Whit-week, the Textile Institute is holding its annual Conference in London, and in association with this event, it has been arranged to hold an exhibition of apparatus, and testing devices for scientific and industrial research in relation to textiles. The exhibits will be staged at the headquarters of the Conference, the Hotel Victoria, Northumberland Avenue, London, W.C.2. The exhibition will be opened by Dr. Harry Moore, director of research of the British Scientific Instrument Research Association, at 3 p.m. on June 3, and remain open until 9 p.m. On June 4 and 5 the exhibition will be open from 10 a.m. to 7 p.m. The exhibits will include a ring wool friction testing machine; whirling-light rotoscope; hygrometers ; thermographs; recording pyrometers, pressure gauges, trichromatic colorimeter ; microscopes ; time regulators ; ultra violet equipment ; X-ray apparatus ; colour comparators; spectrophotometers; colloid mills; and devices for controlling and recording temperature, humidity and pressure. A descriptive catalogue of exhibits will be issued free to all visitors. Further particulars and tickets of admission are available from the Textile Institute's headquarters at 16 St. Mary's Parsonage, Manchester 3.

\section{Gift to the Royal College of Surgeons}

A Generous donation of $£ 25,000$ has been made by the Bernhard Baron Trustees to the Royal College of Surgeons for the erection of new research laboratories. This gift will, by the provision of additional and up-to-date facilities at the College, give a further impetus to research on problems of surgical interest. A research institute for surgery in the centre of London will provide opportunities for those interested to carry on their investigations under the best possible conditions. In this way, the College will have in the future an increased share in the maintenance of London's reputation as one of the great centres of surgical treatment and research.

\section{Medal Awards at the Franklin Institute}

Aт a meeting of the Franklin Institute, Philadelphia, on May 20, the following medal awards were made: Franklin Medals to Dr. Frank Baldwin Jewett, vice-president of the American Telephone and Telegraph Company and president and director of the Bell Telephone Laboratories, for his many important contributions to telephony alone and in collaboration with other workers in the great laboratory of research which he has directed with such signal success, and to Dr. Charles Franklin Kettering, vice-president and director of the General Motors Corporation and general director of the General Motors Research Laboratories, Detroit, for his contributions to the science of automotive engineering; Elliott Cresson Medals to Dr. George O. Curme, jun., of Carbide and Carbon Chemicals Corporation, New York City, for his work on synthetic aliphatic compounds based upon the olefines as starting material and their use in industry, and to Dr. Robert J. Van de Graaff, of the Massachusetts Institute of Technology, for his development of an electrostatic generator for the production of high-voltage direct currents ; Edward Longstreth Medals to Dr. Alfred V. de Forest, president of the Magnaflux Corporation, New York City, associate professor at the Massa. chusetts Institute of Technology; Major William E. Hoke, consulting engineer, Baltimore, for his work on a method of detection of hidden defects, primarily at or near the surface of magnetic materials; Peter P-G. Hall, president of the Hall Planetary Co., Philadelphia, for his invention and development of machine and cutters for planetary milling and threading ; Elmer A. Sperry, jun., vice-president of Sperry Products, Inc., Brooklyn, N.Y., for his development of blind-flying instruments employing gyroscopic principles; John Price Wetherill Medal to Albert L. Marsh, president of the Hoskins Manufacturing Co., Detroit, Michigan, makers of electric furnaces, pyrometers and resistance wire; Walton Clark Medal to Dr. Joseph Becker, of the Koppers Construction Company, Pittsburgh, Pa., for his improvements in the art of carbonisation of coal and manufacture of gas in coke ovens, and particularly for his work in the development of the oven known as the 'Becker Oven'; Louis Edward Levy Medal to Mayo D. Hersey, of Brown University, for his papers on the theory of lubrication, published in the June, July, August and September issues of the Journal of the Institute for 1935 ; Howard N. Potts Medal to Dr. Felix A. Vening Meinesz, Amersfoort, Holland, professor of geodesy and geophysics at the University of Utrecht, for his work in geodesy, and for the development and use of apparatus for determining gravity at sea.

\section{Announcements}

Sir Robert Hadfield has been elected a foreign member of Group 1 (Mathematical and Natural Sciences) of the Norwegian Academy of Sciences and Letters. This group of the Academy is limited to 110 Norwegians and 100 foreigners; among the latter are Sir William Bragg, Sir Frederick Gowland Hopkins, Lord Moynihan, Lord Rutherford, Sir Napier Shaw, Sir Grafton Elliot Smith and Sir J. J. Thomson. 
THE honorary gold medal of the Royal College of Surgeons has been awarded to Dr. J. A. Murray "in appreciation of his services as director of the laboratories of the Imperial Cancer Research Fund". Mr. R. B. Wade, president of the Royal Australasian College of Surgeons, has been elected into an honorary fellowship of the College.

Dr. Albert Defant, professor of oceanography and geophysics at the University of Berlin, has been elected a foreign member of the Swedish Society of Anthropology and Geography, and has been awarded the Galathea Medal of the Royal Danish Geographical Society of Copenhagen.

At a council meeting of the Royal Aeronautical Society held on May 12, Mr. H. E. Wimperis, director of research in the Air Ministry, was elected president for the year 1936-37. At the same meeting, Mr. F. Handley Page was elected a vice-president of the Society for the year 1936-37, and Major T. M. Barlow was re-elected vice-president for a further year of office.

Prof. A. Kopfr, professor of theoretical astronomy in the University of Berlin, will deliver the George Darwin Lecture at the ordinary meeting of the Royal Astronomical Society on Wednesday, June 10, taking as his subject "Star Catalogues, especially those of Fundamental Character."

Dr. C. Montague Cooke, jun., malacologist on the staff of Bernice P. Bishop Museum, has been elected. corresponding member of the Natural History Museum, Vienna, in recognition of his publications and work in assembling materials and records relating to Pacific land snails.

Mr. H. J. PAGE has been appointed to succeed Lieut.-Col. B. J. Eaton, who is retiring shortly from the post of director of the Rubber Research Institute, Malaya. Mr. Page, who is at present controller of agricultural research at the Agricultural Research Station maintained by Imperial Chemical Industries, Ltd., at Jealotts Hill, will be leaving England for Malaya in July next.

ON the occasion of the visit to Bath on May 16 of the Section of the History of Medicine of the Royal Society of Medicine, Sir D'Arcy Power unveiled a memorial tablet of John Hunter on the wall of 12 South Parade, where Hunter lived in 1785, and Dr. F. G. Thomson delivered an address on some early Bath physicians and their times.

Prof. E. V. Appleton will deliver three lectures on "Some Problems of Radio Communication" in the Fyvie Hall of the Polytechnic, Regent Street, London, on Thursdays, June 11, 18 and 25 at 6.30 p.m.

THE following appointments have recently been made by the Secretary of State for the Colonies: W. F. Steven, to be plant pathologist, Agricultural
Department, Gold Coast; J. M. W. Ware, to be veterinary officer, Department of Animal Health, Gold Coast.

The German Society of Natural Science and Medicine will hold its annual Congress at Dresden on September 21-24.

A School for Sanitary and Social Education was opened on March 7 at Prague at the expense of the State, supported by the Rockefeller Foundation.

Applications are invited for the following appointments, on or before the dates mentioned :

A tutor in mathematics in Loughborough College, Leicester-The Registrar (May 25).

A teacher of engineering in the Technical College, Walthamstow-The Clerk to the Governors, 263 High Street, Walthamstow, E.17 (May 25).

A lecturer in mechanical engineering (aerodynamics and aircraft design) in the Coventry Technical College -The Director of Education, Council House, Coventry (May 28).

A teacher of mathematics in the Northern Poly. technic, Holloway, London, N.7-The Clerk (May 29).

An assistant lecturer in engineering in the Technical College, Cardiff-The Director of Education, City Hall, Cardiff (May 30).

A junior scientific officer in the Wood Chemistry Section of the Forest Products Research Laboratory, Princes Risborough, Aylesbury-The Establishment Officer, Department of Scientific and Industrial Research, I6 Old Queen Street, Westminster, S.W.1 (May 30).

A demonstrator in botany in Westfield College, London, N.W.3-The Principal's Secretary (June 1).

An assistant lecturer and research worker in physio. logy in King's College, London-The Secretary (June 2).

Technical assistants (physics or engineering) at the Signals Experimental Establishment, Woolwich Common, S.E.18 - The Superintendent (June 2).

Civilian technical officers (physies or engineering) in the Admiralty Technical Pool--The Secretary of the Admiralty (C.E. Branch), Whitehall, London, S.W.1 (quote C.E. 2915/36) (June 6).

An assistant lecturer in geology (specially qualified in stratigraphy and palæontology) in the University of Birmingham-The Secretary (June 6).

A research assistant for investigation of the mackerel fisheries at the Marine Biological Labora. tory, Plymouth-The Principal (June 10).

A lecturer in zoology in Armstrong College, Newcastle-upon-Tyne-The Registrar (June 13).

A mining engineer under the Safety in Mines Research Board-The Under-Secretary for Mines, Establishment Branch, Mines Department, Dean Stanley Street, Millbank, Westminster, S.W.I (June 16).

A lecturer in physics in the Heriot-Watt College, Edinburgh-The Principal.

An assistant in the Intelligence Section of the Plant and Animal Products Department of the Imperial Institute, South Kensington, S.W.7-The Establishment Secretary. 